logos_i_ethos_2017_1_(44), s. 115-137

DOI: http://dx.doi.org/10.15633/lie.2124

Tadeusz Biesaga SDB

Uniwersytet Papieski Jana Pawła II w Krakowie

\title{
Deformacje sumienia. Pseudonormy w ujęciu Dietricha von Hildebranda
}

\section{Pseudonormy a amoralne $i$ antymoralne idole}

Tym, co zakłóca formułowanie słusznych sądów sumienia, są funkcjonujące $\mathrm{w}$ naszej świadomości moralnej substytuty moralne, albo inaczej pseudonormy. Niezależnie od tego, czy powstają one przez nas w sposób zawiniony czy niezawiniony, czyli czy nabywamy je świadomie czy też w wyniku naszej naiwności, zniekształcają one nasze sądy dotyczące dobra moralnego ${ }^{1}$. Owe pseudonormy Dietrich von Hildebrand dzieli na: 1) substytuty formalne (the formal subsitute) oraz 2) substytuty materialne lub jakościowe (material or qualitative substitute).

1 Zagadnieniu substytutów moralnych poświęca Dietrich von Hildebrand swoje prace: Graven Images: Substitutes for True Morality, New York 1957; wyd. niem. Substitute für wahre Sittlichkeit, w: Idolkult und Gotteskult, Regensburg 1974, s. 13-190 (Gesammelte Werke, 7); Liturgie und Pesönlichkeit, w: Idolkult und Gotteskult, dz.cyt., s. 191-300; pewne części: Christian Ethics, New York 1952; wyd. niem. Ethik, Regensburg 1973 (Gesammelte Werke, 2). Opracowanie tej tematyki: J. Gorczyca, Dietricha von Hildebranda koncepcja poznania wartości moralnych, „Analecta Cracoviensia" 19 (1987), s. 427-439; T. Biesaga, Świadomościowe i osobowe warunki odpowiedzialności, w: O odpowiedzialności. Moralny wymiar odpowiedzialności w życiu publicznym, red. J. Pawlica, Kraków 1993, s. 67-74 oraz w „Studia Philosophiae Christianae” 29 (1993), nr 2, s. 27-37; D. Wiśniewska, Rodzaje i rola substytutów w moralności w ujęciu Dietricha von Hildebranda, „Logos i Ethos” $2014 \mathrm{nr} 2$ (37), s. 77-98. 
Pierwsze nazywają się formalnymi, ponieważ w miejsce posługiwania się autentycznymi normami moralnymi, kierujemy się w swych sądach i w postępowaniu normami pozamoralnymi, takimi jak a) prawo państwowe (laws of the state), b) tradycja (tradition) lub c) ideologia progresywizmu czy liberalizmu (progressiveness or liberalism).

Natomiast w substytutach materialnych, czyli jakościowych, treściowych moralność utożsamiamy z a) tym, co jest godne lub niegodne osobistego honoru (honorable and dishonorable), b) z tym, co jest spontaniczne, uczuciowe (hummanneness, warmth of heart), c) z tym, co jest obowiązkiem (duty) lub d) z wiernością, lojalnością wobec przyjaciół, e) z postawą altruizmu (altruism), f) postawą samokontroli (selfcontrol), g) postawą unikania czegokolwiek ryzykownego (never too much), h) z dopasowaniem się do tego, co zgodne z przyzwoitością (decent man) czy też i) z ideałem dżentelmena (ideal of the gentelman) itp. ${ }^{2}$

Substytuty moralności są to funkcjonujące w świadomości standardy normatywne, które regulują postępowanie, jako postępowanie zgodne z wartościami, powinnościami i normami moralnymi, mimo tego, że zakresowo i treściowo nie pokrywają się z tym, co wyznaczają właściwe wartości i normy moralne ${ }^{3}$. Substytuty moralności odróżniamy od właściwych norm moralnych przez to, że zastępują i naśladują one formalnie i w jakiejś mierze materialnie, czyli treściowo normy moralne, ale nimi nie są. Zastępują one moralność opartą na poznaniu wartości moralnych i adekwatnej odpowiedzi na wartości ${ }^{4}$ tym, co nakazuje prawo stanowione albo zastana tradycja, lub tym, co wyznaczają uznane za najważniejsze, pewne wartości pozamoralne, doniosłe moralnie lub wyselekcjonowane i odizolowane od innych pewne wartości moralne, przykładem takich substytutów są honor, wierność i lojalność, przyzwoitość,

2 Zob. D. v. Hildebrand, Graven Images: Substitutes for True Morality, dz. cyt., s. 39-51.

3 Zob. D. v. Hildebrand, Graven Images: Substitutes for True Morality, dz. cyt., s. 6.

4 Jakie są odpowiedzi na wartość, na czym polega ich zgodność z wartościami zob. D. v. Hildebrand, Christian Ethics, dz. cyt., s. 191-241; T. Biesaga, Dietricha von Hildebranda epistemologiczno-ontologiczne podstawy etyki, Lublin 1989, s. 107-134; T. Biesaga, Spór o normę moralności, Kraków 1998, s. 81nn; T. Biesaga, Emocjonalna odpowiedź na wartość u podstaw życia moralnego, w: Konteksty podmiotowej świadomości, red. E. Podrez, R. Moń, Olecko 2003 (Episteme, 29), s. 91-100. 
czy też osobista spontaniczność, autentyczność i wierność samemu sobie. Pseudonormy nie obejmują całej sfery moralnej, wypaczają ją, czyniąc zobowiązaniami moralnymi to, co nimi nie jest, lub odwrotnie - wykluczając właściwe zobowiązania moralne.

Substytuty moralności należy odróżnić od innego typu deformacji świadomości moralnej osoby. Różnią się one od patologicznych deformacji sfery moralnej. Patologiczne presje powstają poza naszą racjonalną świadomością i popychają ludzi do różnych czynów. Wymagają one ustalenia psychiatrycznych czy psychologicznych przyczyn owych procesów czy stanów biologicznych i psychicznych, i zastosowania właściwej do tego terapii.

Pseudonormy różnią się również od przyjętych antymoralnych i amoralnych idoli, wzorców postępowania (anti-or a-moral ideals $)^{5}$. Hildebrand do antymoralnych teorii, które odrzucają moralność na rzecz doznań przyjemności, zalicza hedonizm Arystypa z Cyreny. Odrzucenie przez niego ważności samej w sobie (importance-in-itself), a nawet obiektywnego dobra dla osoby, na rzecz tego, co subiektywnie przyjemne i zadawalające, jest odrzuceniem nie tylko jakościowego wymiaru moralności, ale również jej formalnego wymiaru, tkwiącego w zobowiązaniu moralnym. Oba te wymiary są dla Arystypa iluzoryczne, należy je zlikwidować w celu subiektywnego doznania przyjemności. Człowiek mądry według niego to taki, który nie akceptuje żadnej normy i kieruje się tylko poszukiwaniem subiektywnego zadowolenia. „Poszukiwanie przyjemności w rozumny sposób - według Arystypa z Cyreny - nie jest adresowane do naszego sumienia, nie jest powinnością moralną, jeśli nie dostosujemy się do niego, nie sprawia, że czujemy się winni. Niepowodzenie w dostosowaniu się do niego nie jest bowiem sprawą nikczemności, lecz głupoty"6. To samo stanowisko można znaleźć u Machiavellego, który również zaleca, aby się nie troszczyć o to, czy coś jest moralnie dobre czy złe, lecz czy jest zaplanowane i korzystne. W obu teoriach usuwa się moralną powinność, którą - nawet gdyby nas niepokoiła - należy odrzucić.

5 Zob. D. v. Hildebrand, Graven Images: Substitutes for True Morality, dz. cyt., s. 4.

6 D. v. Hildebrand, Graven Images: Substitutes for True Morality, dz. cyt., s. 7. 
W teorii zaproponowanej przez Fryderyka Nietzschego mamy do czynienia $\mathrm{z}$ walką z tym, co wyraża formalny eidos moralności. „Odrzuca on normy, które nakładałyby na nas powinność ich przestrzegania, które apelowałyby do naszego sumienia; chce «wyzwolić» człowieka, likwidując pojęcie winy. Chce zastąpić moralność jako taką przez coś radykalnie amoralnego, które w swym najbardziej formalnym charakterze nic nie ma wspólnego z moralnością" .

Jeśli nawet w propozycji nadczłowieka przyjmuje formalne znaczenie wartości, to jednak nie uzasadnia jej, ani z pozycji tego, co subiektywnie zadawalające, ani z pozycji obiektywnego dobra dla osoby. Przyjmuje odgórnie bez dowodu, że idea nadczłowieka jest najwyższą wartością, można powiedzieć wartością pozamoralną, którą należy realizować, odrzucając istnienie wartości moralnych, będących efektem resentymentu. Wypowiada wojnę sferze moralnej i zastępuje ją przez wartości pozamoralne.

Teoria Nietzschego i podobne teorie nie są wprost substytutem moralności, ponieważ substytut jest bardziej czy mniej przeżywaną i spontanicznie stosowną przez kogoś normą moralności albo standardem postępowania, a filozoficzna teoria wprost taką normą nie jest. Można jednak pytać, w jaki sposób skonstruowana przez kogoś teoria może stać się pseudonormą postępowania.

Hildebrand analizuje tę kwestię na przykładzie Raskolnikowa ze Zbrodni i kary Fiodora Dostojewskiego. W tym przypadku Raskolnikow nie odrzuca wszelkich wartości moralnych, podziwia wiele z nich i potępia postawy niemoralne, jednak nie rozumie nienaruszalności czy świętości życia ludzkiego. Nie mamy u niego do czynienia z jakimiś widocznymi trudnościami na poziomie doświadczania, uchwytywania wartości moralnych. Po zamordowaniu starej kobiety, przeżywa on horror swego czynu, miota się pod ciężarem wyrzutów sumienia i desperacko szuka uwolnienia od tego ciężaru. Co więc skłoniło go do owego morderstwa? Do czego się odwołuje, chcąc wywikłać się z winy? Tym, co go skłoniło do zbrodni, było przekonanie, uzasadniane przyjętą teorią, że

\footnotetext{
7 D. v. Hildebrand, Graven Images: Substitutes for True Morality, dz. cyt., s. 4.
} 
życie tej oto starej kobiety nie stanowi wartości, a jej pieniądze mogą być użyte do promocji jego intelektualnych i twórczych talentów. Tak więc teoria, w której wartości pozamoralne, wartości intelektualne zostały wyniesione na piedestał, wpłynęła na zrelatywizowanie wartości czyjegoś życia. Raskolnikow nie zawierzył swojemu bezpośredniemu doświadczeniu moralności, lecz uzależniał je od przyjętej i rozwijanej przez siebie teorii. Uznał, że jego doświadczenie wartości moralnych jest tylko konstruktem społecznym, który łatwo można, a nawet należy podważyć w swych intelektualnych deliberacjach. W związku z tym jego intelektualna argumentacja idzie w kierunku podkreślania wartości własnego geniuszu, który jest potrzebny i konieczny dla ludzkości, a który może się rozwinąć dzięki pieniądzom owej starej kobiety. W ten sposób rozwijana i przyjmowana przez niego błędna teoria tworzy w nim przekonanie o słuszności zlikwidowania niepotrzebnej kobiety. Można to nazwać teoretyczną moralną częściową ślepotą na pewne wartości moralne. Skonstruowana przez kogoś teoria staje się tu zasłoną zakrywającą pewne wartości moralne czy moralnie doniosłe, wprowadzającą zamęt $\mathrm{w}$ nasze przekonania, sugerując w nich, że nasze doświadczenie wartości życia drugiej osoby, jako wartości nienaruszalnej, jest mylące, gdyż wartość ta jest wartością konwencjonalną, kulturową, która nie ma charakteru kategorycznego zobowiązania moralnego. W ten sposób błędna teoria wprowadza perwersję w dziedzinę przekonań i usprawiedliwia niemoralne działania.

Opis ślepoty wywołanej błędną teorią, która zasłania pewne wartości moralne i wyklucza je $\mathrm{z}$ grona wartości generujących powinność moralną, ujawnia pewne mechanizmy tworzenia się pseudonorm w naszej świadomości moralnej. Ślepota bowiem wywołana zaakceptowaną i tworzącą moje przekonania aksjologiczne teorią może współgrać ze ślepotą wynikłą z przeakcentowania wartości pozamoralnych (overemphasis on extra-moral values) oraz z wpływu pychy i pożądliwości (pride and concupiscence $)^{8}$. Raskolnikow bardzo cenił wartości pozamoralne, ucieleśnione w wybitnych intelektualnie i silnych osobowościach, które 
skutecznie dążą do swych celów. Ów podziw i cześć dla skuteczności i siły wielkich osobowości podważały w nim mniemanie o wartości życia owej miernej, starej kobiety. Obok przeakcentowania doniosłości wartości intelektualnych, możemy dostrzec u niego również jego wyniosłe, pyszne ego, które swoją wartość widzi nie w realizacji wartości moralnych, ale w realizacji intelektualnych talentów. Tak więc różne formy częściowej ślepoty na wartości moralne mogą być skutkiem przyjętej błędnej teorii, przeakcentowania pozamoralnych wartości oraz wpływu naszego pysznego i pożądliwego ja osobowościowego.

\section{Pseudonormy legalizmu i anarchizmu}

W stosunku do amoralnych i antymoralnych idoli, które całkowicie odrzucają moralność, substytuty moralne wyróżniają się tym, że spełniają w naszej świadomości funkcję normy moralności, rolę kryterium dobra i zła. W zależności, jakie to są pseudonormy, w różny sposób deformują one sferę moralną.

Prawo stanowione może stać się dla wielu ludzi substytutem, pseudonormą moralną, zastępującą właściwe normy moralne. Państwo jako takie jest ważnym i niezbędnym dobrem indywidualnej osoby i społeczności. Jest ono stróżem porządku i sprawiedliwości społecznej. „Autorytet państwa we właściwych ramach jest słuszną normą. Prawo państwowe winno być respektowane dopóki nie przybiera niemoralnego charakteru, dopóki nie przekracza sfery kompetencji autorytetu państwa"'. Nawet jeśli ktoś stanie na stanowisku, że prawo państwowe obowiązuje nas moralnie, to jednak nie można prawa i autorytetu państwa utożsamić z moralnością. Prawo stanowione jest jednym wśród wielu innych moralnie doniosłych dóbr (morally relevant good) i przez wiele z nich, ze względu na ich wyższą rangę, może być przewyższone ${ }^{10}$. Zrównanie czy zastąpienie kategorycznej powinności moralnej, majestatu i metafizycznej głębi sfery moralnej autorytetem państwa jest grubiańskim i prymityw-

\footnotetext{
9 D. v. Hildebrand, Graven Images: Substitutes for True Morality, dz. cyt., s. 133.

10 Zob. D. v. Hildebrand, Graven Images: Substitutes for True Morality, dz. cyt., s. 134.
} 
nym błędem. Prowadzi to do zastąpienia najgłębszej sfery życia człowieka lojalnością (loyalty) wobec pewnej zewnętrznej struktury społecznej. Lojalność taką traktuje się jako podstawową cnotę, reprezentującą całą rzeczywistość moralności. Lojalność wobec autorytetu państwa wobec prawa stanowionego jest wtedy równoznaczna $\mathrm{z}$ byciem sprawiedliwym i moralnie dobrym człowiekiem. Zakres moralności ograniczony jest do tego, co nakazane prawem państwowym.

Taką pomyłkę może wzmacniać fakt prawa karnego. W prawie tym wyznaczone są i egzekwowane kary za popełnione zło. W tym wypadku ujawnia się wyraźnie związek prawa karnego z moralnością. Państwo, karząc zbrodnie, kradzieże itp., czyni to również w imię moralności. Podkreśla w ten sposób dobra chronione prawem stanowionym, które jako dobra doniosłe moralnie są chronione również prawem moralnym. Nawet przy takiej zbieżności prawa stanowionego i moralności trzeba zauważyć, że kara państwowa nie jest tym samym, co pokuta za wyrządzone zło, za grzechy. Nawet jeśli państwo po odbyciu kary wybacza przestępcy, to jednak o wybaczenie za zbrodnie powinniśmy prosić nie tylko ludzi, a przede wszystkim Boga. W przypadku bowiem zbrodni, ani państwo, ani bliscy ofiary nie mają możliwości wybaczyć tego zła, które jest nieodwracalne. Mogą wybaczyć tylko swój ból utraty kogoś i zwrócić się do miłosierdzia Boga. Wyraża to powiedzenie: „ja ci przebaczam, oby Bóg ci wybaczył". Sięgamy tu głębi misterium dobra i zła, misterium odkupienia i zbawienia.

Nie negując pożytku prawa stanowionego i prawa karnego, trzeba dostrzec różnice między porządkiem i zasadami prawnymi a zasadami i normami moralnymi. Moralność może mieścić w sobie to, co zakazuje i karze prawo karne, ale się do tego zarówno w swym zakresie, treści, jak i głębi nie ogranicza. Państwo nie karze braku miłości czy pokory, zazdrości, nienawiści, obojętności religijnej itp., a są to wady moralne. Niemniej prawo karzące zbrodnie podkreśla ważność norm moralnych i stąd łatwo można go potraktować jako uobecniające istotę moralności, moralność jako taką. Ktoś może bowiem potraktować autorytet państwa i prawo stanowione jako rzeczywisty obszar moralnych zobowiązań, a inne zobowiązania odsunąć jako mgliste i dowolne. Może stawiać na 
tym samym poziomie nakazy państwowe i przykazania moralne. W ten sposób zbliża się do sytuacji zastąpienia moralności pseudonormą prawa stanowionego. Czyni to biurokrata moralny, u którego zanikła wrażliwość i przeżycia moralne, na rzecz ślepego spełniania nakazów instytucji państwowych.

Prawo stanowione staje się w pełni substytutem moralnym wtedy, gdy ktoś w swych przeżyciach utożsami nakazy państwowe z powinnościami moralnymi ${ }^{11}$. W tej sytuacji źródłem zasad moralnych nie jest przeżycie wartości moralnych czy przeżycie godności osoby, czyli przeżycie sfery wartości w ich swoistości i hierarchicznym uporządkowaniu, co zakłada uchwycenie swoistości, kategoryczności i głębi wartości moralnych jako takich. W miejsce bezpośredniego, intuicyjnego poznania wartości wkracza zewnętrzny nakaz państwowy. W owym przecenieniu autorytetu prawa stanowionego bledną albo zanikają właściwe źródła i kryteria dobra i zła, a moralne staje się tylko to, co nakazuje konwencjonalne prawo stanowione.

Można w tym procesie wyróżnić dwa zniekształcenia sfery moralnej. Pierwsze polega na nadaniu wszystkiemu, co nakazuje prawo stanowione, charakteru nakazów moralnych, drugie - jeszcze gorsze - na ograniczeniu całej sfery moralnej tylko do tego, co nakazuje prawo stanowione. W pierwszym przypadku za moralne będzie się uznawać również pozamoralne i niemoralne nakazy prawa stanowionego, w drugim przypadku całą moralność zacieśni się do prawa stanowionego, czyli wykluczy się z moralności to, co przekracza prawo stanowione, traktując te wartości i normy jako nieważne lub dowolne. Deformacja moralności w drugim przypadku jest największa, ponieważ nie tylko pozamoralne i niemoralne nakazy prawa stanowionego zostają uznane za moralne, ale szerokie spektrum obowiązujących nas powinności moralnych zostanie zlikwidowane w imię i na rzecz wąskiego zbioru moralnie doniosłych, pozamoralnych i niemoralnych nakazów państwa. Państwo - Lewiatan obleka się wtedy w majestat niejako boski, wyznaczający dla nas to, co jest dobre, a co złe, majestat decydujący o naszym człowieczeństwie, niejako o naszym

11 Zob. D. v. Hildebrand, Graven Images: Substitutes for True Morality, dz. cyt., s. 135. 
zbawieniu. Państwo staje się idolem, a nasza postawa wobec niego staje się idolatrią. Moralność w tym substytucie, w tej idolatrii odarta jest z prawdziwego absolutnego charakteru, który za Kierkegaardem można nazwać „tchnieniem wieczności”, jest ona zsekularyzowana, spłaszczona, odarta ze swej głębi i zastąpiona czcią dla ziemskich bałwanów.

Zastąpienie moralności pseudonormą prawa stanowionego, czyli rzeczywistością konwencjonalną, odziera moralność z jej właściwej natury, prowadzi bowiem do odrzucenia jej uniwersalnej obowiązywalności, do relatywizacji jej ważności. Moralność staje się sprawą gustu, ustalania, zmian i silnych wpływów w legalizacji np. dewiacji indywidualnych i społecznych.

Jeżeli w substytutach formalnym dochodzi do przeakcentowania zewnętrznych źródeł moralności, takich jak państwo, rasa, klasa, kultura, obyczaj, ideologia postępu itp., to w substytutach jakościowych, dochodzi do przeakcentowania wewnętrznych, podmiotowych źródeł moralności. Można nawet powiedzieć, że podmiotowe zniekształcenia źródeł moralności są skrajną reakcją na normatywność, nakazowość zewnętrzną oraz na nakazowość autentycznych, kategorycznych powinności moralnych.

W substytutach jakościowych moralność utożsamiana jest $\mathrm{z}$ wartościami personalnymi, osobowościowymi, doniosłymi moralnie lub wprost moralnymi, przybierającymi rolę kryterium dobra i zła, rolę normy moralności jako takiej. Tak np. poczucie honoru, autentyczności, spontanicznej impulsywności, serdeczności czy wrażliwości, a nawet osobistego altruizmu są wartościami personalnymi, ale mogą stać się substytutami moralności, zniekształcającymi to, co wyznaczają wartości moralne.

Potraktowanie w sobie niezależności, wolności, autentyczności, nieskrępowanej, emocjonalnej spontaniczności jako wyrazu istoty moralności jako takiej może być reakcją obronną wobec narzuconej moralności z zewnątrz, czy też reakcją na zbyt silnie odczuwaną normatywność autentycznych wartości moralnych. Wartości moralne charakteryzują się w swej naturze, stopniu hierarchicznym i w swej wyższości względem innych wartości kategorycznością, która nie ustępuje pod naporem czyjeś wolności czy spontaniczności, lecz narzuca nam się w przeżyciu winy. Oskarżenie, ocena naszego ego jest momentem bolesnym, można 
powiedzieć nieznośnym i właśnie wymienione wyżej pseudonormy chcą nas od niego uwolnić.

Ci, którzy kierują się pseudonormą absolutnej niezależności, spontaniczności, autentyczności czy wierności tylko swoim impulsom, wszelkie normy moralne wymagające kontroli tych spontanicznych impulsów mogą potraktować jako zniewalające i opresyjne. Zdaniem Hildebranda takie zachowanie można obserwować szczególnie w narodach słowiańskich. „Każda reguła, każdy nakaz traktowany jest jako nieludzki, zimny, bez serca i przez to konwencjonalny i sztuczny. Moralne dobro identyfikowane jest ze spontanicznością, niekonwencjonalną otwartością, z posiadaniem wrażliwego, wylewnego serca. Moralne zło identyfikowane jest z lojalnością wobec jurydycznych nakazów, z poprawnością, biurokratyzmem lub zimnym racjonalizmem"12.

Tacy ludzie mogą dostrzegać szersze spektrum wartości moralnych, ale osądzają siebie i innych w pierwszym rzędzie według kryterium autentyczności i nieskrępowanej spontaniczności. Nawet jeśli zauważą, że ktoś w swoim impulsywnym postępowaniu zachował się niemoralnie, to jednak oceniają go pozytywnie, jeśli zachował się spontanicznie, wylewnie i szczerze ${ }^{13}$. Osąd moralny kształtowany jest w tym przypadku wyłącznie w oparciu o stwierdzenie, czy coś jest efektem niezależności, spontaniczności, dowolności. Osąd taki usprawiedliwia zło tym, że ktoś zachowuje się spontanicznie, jest wierny tej spontaniczności i do niej się przyznaje. W tej opcji wystarczy ów ekshibicjonizm moralny, pochwalenie się zdradą, aborcją, aby uznać, że mamy do czynienia z autentycznym dobrym człowiekiem i w efekcie autentycznym, czyli dobrym czynem. Osoby przyjmujące substytut spontaniczności i autentyczności w postępowaniu jako kryterium dobra i zła traktują postępowanie moralne, kierowane uniwersalnymi normami, jako zafałszowanie moralności i hipokryzję.

Zwolennicy bezwzględnej autentyczności traktują każdy wysiłek moralny jako cyniczną nieszczerą egzaltację, która stoi w sprzeczności z naturalną szczerością. To właśnie dążenie do moralnego ideału odziera

12 D. v. Hildebrand, Graven Images: Substitutes for True Morality, dz. cyt., s. 41.

13 Zob. D. v. Hildebrand, Graven Images: Substitutes for True Morality, dz. cyt., s. 47. 
według nich naszą naturę z właściwych jej dążeń. Natura ta powinna się bowiem objawiać w jej impulsywności, bezpośredniości i przez to w jej prawdziwości. Dążenie do własnej, moralnej doskonałości traktują oni jako pretensjonalny faryzeizm. Chcą się temu przeciwstawić przez spontaniczne, kontrowersyjne czyny, które mają wstrząsnąć moralnością zastaną, tą która niejako z góry narzuca moralne nieuprawnione wymagania ${ }^{14}$.

Pseudonorma tak pojętej wierności sobie, swojej niezależności i impulsywnej nieskrępowalności „nie tylko zaciemnia prawdziwą hierarchię wartości moralnych, lecz deformuje etos i fałszuje całą sferę moralną"15. Deformacja ta polega po pierwsze na wyizolowaniu i przeakcentowaniu pewnych wartości. Wybrana jedna wartość, np. autentyczność czy spontaniczność serca, nie jest przyporządkowana innym wartościom i normom moralnym, ale rozszerzona na całą sferę moralną, czyli potraktowana jako wyrażająca istotę wartości moralnych, czyli jako kryterium dobra i zła. W ten sposób zostaje zniszczona jakościowa natura wartości moralnych. Po drugie wyselekcjonowania wartość osobowa, jako jedynie właściwa i obowiązująca, przeciwstawiona jest w sposób agresywny innym wartościom moralnym. „Wiele wartości moralnych jest pominiętych i przeoczonych, jak to się dzieje w przypadku tzw. naiwnych substytutów, oraz wiele wartości moralnych jest zepchniętych do sfery pseudomoralnej i zwalczanych"16. W zwalczaniu innych wartości moralnych substytut ten przybiera charakter apostazji heretyckiej. Nie zawsze prowadzi on do wystąpienia np. z Kościoła. Wielu chrześcijan, katolików kierujących się substytutem swej indywidualnej niezależności, nieskrępowanej emocjonalnej impulsywności pozostaje we wspólnocie Kościoła. Niemniej mogą być oni wyraźnie zaangażowani w zwalczanie wielu wartości chrześcijańskich, które według nich ograniczają ich osobiste reakcje, wybory, decyzje. Czyniąc to niejako w imię swej suwerenności, autentyczności swoich wyborów, będą chcieli zmienić nauczanie moralne Kościoła i dostosować je do swoich wyobrażeń. Kierowanie się tylko kilkoma wybranymi

14 Zob. D. v. Hildebrand, Graven Images: Substitutes for True Morality, dz. cyt., s. 47.

15 D. v. Hildebrand, Graven Images: Substitutes for True Morality, dz. cyt., s. 47.

16 D. v. Hildebrand, Graven Images: Substitutes for True Morality, dz. cyt., s. 57-58. 
wartościami prowadzi jednak do oderwania moralności od jej zakorzenienia w humanizmie chrześcijańskim, w chrześcijańskim Objawieniu, do sekularyzacji i relatywizacji tego humanizmu.

Niezależnie od tego, czy powyższy substytut objawia się jako zaangażowanie naiwne czy heretyckie, przemyślane i agresywne, można powiedzieć, że u jego podstaw leży nieuprawnione wyselekcjonowanie z całego spektrum sfery moralnej wybranych przez siebie wartości osobistych, i uznanie ich za normę moralności, za kryterium dobra i zła dla całej sfery moralnej tylko dlatego, że zostały wybrane osobiście.

Postawa spontaniczności i autentyczności odruchów w działaniu otwiera drzwi dla irracjonalności, subiektywności oraz dla namiętności i pychy. Człowiek kierujący się taką pseudonormą łatwo może stać się ofiarą swoich namiętności, uznając, że ich nieskrępowana, spontaniczna realizacja jest wyrazem jego autentyczności i stąd jest czymś dobrym. Mimo wyuzdania czy nawet perwersyjnych zachowań seksualnych, zdrad małżeńskich, będzie się szczycił swoimi czynami, gdyż w nich czuje się wolny od hipokryzji i zakłamania i postępuje zgodnie z odruchami swych stanów cielesnych i emocjonalnych.

\section{Ja pożądliwe i ja pyszne w tworzeniu się pseudonorm moralnych}

W konstytuowaniu się pseudonorm w naszym postepowaniu ważną rolę odgrywa nasz związek z dobrami pozamoralnymi oraz związek z pychą i pożądliwością. Występują w nas przeróżne formy wyciszenia przez ja-prawe-pokorne-miłujące - ja pysznego czy ja pożądliwego oraz różne formy osłabienia, wyciszenia czy wyrugowania aktualnego funkcjonowania ja prawego-pokornego-miłującego na rzecz ja pożądliwego czy ja pysznego. Mogą wystąpić w nas przeróżne mieszanki pychy i pożądliwości skutkujące różnymi formami osłabienia, wyciszenia czy wyrugowaniu ja-prawego-pokornego-miłującego ${ }^{17}$.

17 Opis centrów osobowych sprzyjających i uniemożliwiających właściwą odpowiedź na wartość zob. D. v. Hildebrand, Christian Ethics, dz. cyt., s. 408-452. 
Człowiek owładnięty szatańską pychą traktuje wszelkie nakazy moralne jako narzucone i znienawidzone formy swego zniewolenia. Im wyższe wartości moralne czy religijne, tym bardziej drażnią one jego pychę, co sprawia, że nie tylko je lekceważy, ale podejmuje się zrzucenia ich z piedestału, ich detronizacji i podeptania. Ja satanistycznie pyszne wyżywa się w niszczeniu nieznośnego i znienawidzonego majestatu wartości moralnych, aby upodlić te wartości i przez to się z nich wyzwolić. Nie skupia się ono na budowaniu, ale wyżywa się i doznaje niejako erotyczno-sadystycznej satysfakcji z unurzania w błocie, wyśmiania, upodlenia najwyższych wartości moralnych i religijnych.

W podobny sposób, ale z innych motywów odrzuca zasady moralne ja owładnięte zwierzęcą pożądliwością. Owładnięty namiętnością traktuje moralność, albo jako przeszkodę, albo jako mglistą utopię, która go nie obowiązuje. Pchany pożądaniem wartości pozamoralnych, czy to związanych z jego seksualnością, czy z posiadaniem różnych dóbr materialnych, konstruuje sobie własne zasady podstępu, wykorzystania innych, oszustwa i bezwzględności. Staje się podstępnym, niebezpiecznym drapieżnikiem, wyposażonym nie tylko $\mathrm{w}$ siłę fizyczną, ale i w broń podporządkowanego namiętności rozumu instrumentalnego, który wymyśla skuteczne drogi realizacji owych namiętności.

Ludzie owładnięci pożądliwością czy pychą są bardziej podatni na przyjęcie różnych pseudonorm, substytutów moralności. Można powiedzieć, że z definicji są oni otwarci na pseudonormy moralne. Warunkiem bowiem dania adekwatnej odpowiedzi na wartość jest prymat w nas ja-prawego-pokornego i miłującego. Adequatio cordis et voluntatis ad valorem wymaga uwolnienia się tego ja, od decydującej roli ja pysznego i ja pożądliwego. Uzgadnianie się z wartościami moralnymi wymaga otwartości poznawczej, otwartości naszego serca, by dać odpowiedź zgodną z naturą tych wartości, z pozytywnością czy negatywnością wartości, ze stopniem hierarchicznym danej wartości, tak aby nasza wola poszła za tym, co poznano i przeżyto jako powinność moralną, w celu zrealizowania danej wartości.

W przypadku dominacji ja satanistycznie pysznego czy ja zwierzęco pożądliwego adekwatna odpowiedź na wartości moralne zastępowana 
jest odpowiedzią na wartości pozamoralne i antymoralne. W ten sposób człowiek owładnięty przez pychę czy pożądliwość jest otwarty na zastąpienie moralności czymś innym. W przypadku prawa stanowionego łatwo może przyjąć, że to, z czym trzeba się liczyć w realizacji ego pysznego czy ego pożądliwego, to prawo stanowione, prawo karne. Może on zaakceptować ten substytut z czysto utylitarnych powodów, czyli dlatego, że są zbyt duże koszty realizowania swoich celów, i podlegania wyrokom, że lepiej być lojalnym, szanowanym obywatelem, bo mając ten szacunek, łatwiej będzie można wyprowadzić innych w pole, wspiąć się w karierze społecznej i zyskać więcej dóbr zaspakajających swe pożądanie czy pychę.

Człowiek taki może chcieć być lojalnym, szanowanym obywatelem, gdyż w ten sposób nie jest wykluczony ze społeczności przez napiętnowanie wyrokiem czy karą więzienia. Inaczej mówiąc, dostrzega on pożytek lojalności dla realizacji jego ego zdominowanego przez pożądanie, ponieważ na tej płaszczyźnie praktycznie zrealizuje więcej egoistycznych celów, niż spychając się na margines społeczny.

Tym bardziej substytut lojalności wobec państwa zaakceptuje człowiek zdominowany pychą, ponieważ państwo pychy nie kwestionuje, tak jak to czyni prawo moralne. Jego pysze może nawet sprzyjać uczestnictwo w życiu społecznym i politycznym, w różnych gremiach cieszących się uznaniem, w piastowaniu ważnych stanowisk, w otrzymywaniu odznaczeń. W ten sposób lojalność wobec państwa pozwala pyszałkowi wyzwolić się od zasad moralnych, zastąpić moralność prawem stanowionym, a do tego jeszcze uchodzić za szlachetnego uczciwego moralnie człowieka, czyli wykorzystać wartości moralne dla realizacji swego egoizmu ${ }^{18}$.

Również dla człowieka opanowanego pożądliwością prawo stanowione jawi się jako mniej wymagające niż moralność i stąd jest bardziej atrakcyjne niż prawa moralne. Choć narzuci mu ono ograniczenia względem jego pożądania, szczególnie jeśli chodzi o to, co należy do sąsiada, do drugiego obywatela, to jednak pyszałek, zachowując się jako lojalny obywatel, znajdzie niezliczone możliwości zaspakajania swego pożądania w czynach, których zabrania prawo moralne. „Potępienie pożądliwości 
jest tylko ograniczone do pewnych zbrodni, gdy tymczasem konfrontacja z ostateczną powagą i majestatem prawa moralnego jest większym skandalem dla pożądania niż podporządkowanie się prawu stanowionemu"19. Substytut legalizmu wobec państwa niszczy nie tylko moralność jednostki, ale i społeczeństwa. Umożliwia on bowiem powstawanie niezwykle niebezpiecznych zjawisk społecznych. Otwiera drzwi dla groźnych ideologii. Przez wzmacnianie pychy łatwo bowiem można rozbudzić postawy egoizmu partyjnego, klasowego czy narodowego. Nazizm czy komunizm, inspirowane pychą i pożądaniem, powstały z zawierzenia i bałwochwalstwa względem struktur państwowych i społecznych. Nazizm napędzany był pychą narodu niemieckiego, a komunizm pożądaniem dóbr materialnych posiadanych przez burżuazję. Naziści dokonujący zbrodni na innych narodach tłumaczyli to pychą wyższości rasy, a komuniści, niszcząc inne klasy społeczne, tłumaczyli to pożądaniem posiadania tego, co posiadali inni. Obie ideologie wzmacniały swoje destrukcyjne działania przez legalizację w strukturach państwowych zbrodniczych działań.

W dość subtelny sposób pycha może wspierać substytuty związane $\mathrm{z}$ indywidualnym ego, które $\mathrm{w}$ ocenie siebie wybiera pewne swoje pozamoralne wartości osobowe, takie choćby jak niezależność, autentyczność, spontaniczność, honor, odwaga itp. Wartości te, zaspakajając czyjeś egoistyczne poczucie wielkości, utwierdzają go w tym, że nikt inny, tylko on sam ma wyznaczać sobie, co jest ważne, cenne i obowiązujące. Pychę z zasady drażnią wartości i powinności moralne. Im w hierarchii wartości moralne są wyżej, tym bardziej są denerwujące i nieznośne. Pyszałek szczycący się wyniosłą niezależnością i odwagą z zasady skieruje się do niszczenia najwyższych wartości i norm moralnych, które pretendowałyby do ograniczenia jego wybujałego ego. Może to czynić w imię różnych pozamoralnych wartości, zaspokających jego ja pyszne i pożądliwe. Człowiek taki, np. jako artysta, w imię wartości estetycznych może niszczyć subtelne wartości moralne czy religijne. Mogą temu służyć satanistyczne performanse, w których w imię rzekomych wartości estetycznych, artystycznych, kulturowych miesza się z błotem wartości

19 D. v. Hildebrand, Graven Images: Substitutes for True Morality, dz.cyt., s. 139. 
moralne i religijne. W satanistycznej, nihilistycznej destrukcji wartości chrześcijańskich używa się wtedy rzeczywistych i rzekomych wartości pozamoralnych, takich jak czyjaś wolność, talent muzyczny, literacki czy teatralny itp. Owe postawione na szczycie pozamoralne wartości, przez zaspokojenie pychy i pożądania, stają się idolem, który skłania do detronizacji i destrukcji właściwych wartości moralnych.

Odkrycie w sobie pseudonorm, substytutów moralności, umożliwia przezwyciężanie deformacji moralnych. „Nie ma wątpliwości - pisze Hildebrand - że prawdziwa moralność nakazuje nam oczyszczenie się $\mathrm{z}$ perwersji powodowanych przez różne substytuty oraz że prawdziwe moralne dobro uwalnia nas od jakościowych substytutów. Ale obalenie substytutów jest uzasadnione tylko wtedy, gdy są one zastąpione prawdziwą moralnością. Jeśli jest jednak przeciwnie i są one zastąpione przez antymoralne idole lub przez kompletną pustkę, wtedy rzeczy ostatnie stają się gorszymi od poprzednich" ${ }^{20}$. Substytuty bowiem w porównaniu $\mathrm{z}$ totalną obojętnością moralną, amoralnymi, antymoralnymi idolami, mimo deformacji moralności, są mniej niszczące moralność, niż wspomniane idole. Należy się wyzwalać z nich w kierunku prawdziwej moralności, a nie przeciw moralności jako takiej.

\section{Od pseudonorm do dojrzałości moralnej}

Opis fenomenologiczny i istotowy różnych typów pseudonorm w świadomości moralnej nie wyczerpuje wszystkich uwarunkowań i czynników, które wpływają na funkcjonowanie naszego sumienia. Ważne są bowiem również uwarunkowania biologiczne, neurologiczne, patologiczne, które oddziaływają na takie, a nie inne formowanie sądów aksjologicznych i moralnych. Analizowane są one w neuronaukach, psychiatrii, psychologii i socjologii moralności ${ }^{21}$. Zarówno interdyscyplinarne czy syntetycz-

20 D. v. Hildebrand, Graven Images: Substitutes for True Morality, dz. cyt., s. 173.

${ }^{21}$ Zob. K. Murawski, Jaźń i sumienie. Filozoficzne zagadnienia rozwoju duchowego człowieka w pracach Carla Gustawa Junga i Antoniego Kępińskiego, Wrocław 1987, passim; R. Stach, Sumienie i mózg. O wewnętrznym regulatorze zachowań moralnych, Kraków 2012, passim; Fenomen sumienia, red. D. Adamczyk, Kielce 2012, passim. 
ne ujęcie tych wszystkich czynników w jedną całość jest bardzo trudne, gdyż każda z tych dyscyplin ma swoje własne założenia metodologiczne i wyznaczony przez nie wąski aspekt swoich badań. Redukcjonizm metodologiczny nie uprawnia do zastosowania w syntezie omawianego zjawiska redukcjonizmu filozoficznego, antropologicznego czy aksjologicznego. W związku z powyższym wglądy w funkcjonowanie osoby na poziomie świadomości moralnej legitymują się swoją autonomią i mogą być prezentowane niezależnie od badań przedstawianych w innych naukach i nurtach filozoficznych. Niemniej poszukiwanie ukrytych, zakładanych uwarunkowań świadomości aksjologicznej oraz sugerowanie praktycznych wskazań do przezwyciężania owych uwarunkowań jest wspólne różnym naukom i nurtom filozoficznym.

W tym względzie fenomenologia i ejdetyka świadomości moralnej ujawnia w ramach swojej metody ukryte uwarunkowania formowania się sądów moralnych i wskazuje drogę do dojrzałości moralnej. Owe praktyczne propozycje są przydatne szczególnie dla etyki, psychologii moralności, samowychowania i rozwoju moralnego i duchowego. Przedstawione wyżej uwarunkowania powstawania pseudonorm polegają na przedkładaniu różnych wartości pozamoralnych nad wartości moralne oraz na wpływie ja pożądliwego i ja pysznego. Do zniekształceń sfery moralnej prowadzą również zaniedbania i błędy w sferze poznania wartości moralnych dotyczące odkrycia ich natury i ich stopnia w hierarchii wartości. Obok sfery czysto poznawczej dużą rolę odgrywa emocjonalna odpowiedź na wartość. Adequatio cordis ad valorem jest bowiem podmiotową i osobistą akceptacją wartości moralnych, dostrzeżeniem i przyjęciem ich specyficznej, kategorycznej powinności moralnej, którą te wartości generują. To właśnie w konstytuowaniu się emocjonalnej odpowiedzi na wartość dokonuje się w nas zasadniczy dramat akceptacji i wyboru między wartościami samymi w sobie a wartościami tego, co subiektywnie zadawalające, oraz wartościami moralnymi a wartościami pozamoralnymi. Wartości moralne ujawniają swoją głębię, są tchnieniem wieczności, odsyłają nas do Boga, umożliwiają przezwyciężenie powierzchownych odpowiedzi na nie oraz przeciwstawienie się różnym pseudonormom kierującym naszym postępowaniem. Tego typu rozwój moralny 
jest możliwy poprzez praktykowanie odpowiedniego życia duchowego. W takim życiu dojrzewamy moralnie do lepszego widzenia transcendencji wartości moralnych względem tego, co tymczasowe, relatywne, przemijające. Dojrzewamy do odpowiedzialności moralnej, przekraczającej osobiste uwikłania psychologiczne, społeczne czy kulturowe. Przekraczamy pseudonormy ufundowane na tym, co jedynie subiektywnie zadawalające, co zaspakaja naszą pożądliwość i pychę, na rzecz obiektywnych powinności moralnych. Przekraczamy pseudonormy ufundowane na wartościach pozamoralnych, propagowanych przez społeczeństwo, państwo, kulturę czy ideologię. Wyzwalamy się ze zniewolenia wewnętrznego i zewnętrznego, zbliżając się do autentycznej wolności, przekraczającej doraźne interesy, w imię wezwania wartości moralnych i moralnie doniosłych, w imię pełni człowieczeństwa, pełni więzi z ludźmi i Bogiem.

Oczyszczanie się z pseudonorm i dojrzewanie do pełni świadomości moralnej bliskie jest temu, co opisuje współczesna psychologia. Hildebrand dość krytycznie odnosił się do psychoanalizy, w której podmiot uwięziony jest $\mathrm{w}$ immanentnej analizie swoich procesów i nie posiada transcendentnych kryteriów dla sądów moralnych ${ }^{22}$. Tego typu wiedza o neutralnych procesach, pomijająca inne obszary ludzkiego życia, jest ułomna, niepełna i niewystarczająca, by być podstawą realnego samopoznania siebie, które jest możliwe w kontekście pełnej prawdy o człowieku. Bliższa fenomenologii aksjologicznej Hildebranda jest psychologia humanistyczna, w której sfera obiektywnych wartości odgrywa zasadniczą rolę w dojrzewaniu świadomości moralnej.

Różne nurty psychologiczne, behawioralne, psychoanalityczne, humanistyczno-egzystencjalne opisują różne warstwy czy aspekty funkcjonowania sumienia. Pierwsze ujmują je w ramach empirycznych psychologicznych i socjologicznych procesów naśladowania, społecznych mechanizmów uczenia się, internalizacji wartości i norm, konstytuowania się ja powinnościowego oraz ja idealnego. Mimo różnic w opisie tych procesów, całościowe ujęcia zbliżają się do teorii rozwojowych, w których wyróżnia się pewne fazy, od fazy konformizmu do fazy kierowania się

${ }^{22}$ Zob. D. von Hildebrand, Przemienienie w Chrystusie, tł. J. Zychowicz, Kraków 1982, s. 41. 
własnymi ideałami, w której dochodzi się do moralności autonomicznej ${ }^{23}$. Na przykład „dziecko podporządkowuje się zasadom oraz normom, jakie narzucają dorośli. [...] Wraz z wiekiem moralność posłuszeństwa słabnie i ustępuje miejsca moralności autonomicznej opartej na obustronnym szacunku wzajemności”24. Dorastający lub dorosły człowiek w ostatnim etapie dojrzałości moralnej jest zdolny przekroczyć fazę konformizmu społecznego, dokonać rewizji własnej konwencjonalnej moralności, ukształtowanej przez aktualną społeczność, kulturę, państwo oraz dzięki autorefleksji, autoanalizie zbudować moralność podmiotową, osobową, autonomiczną. Psychologicznie jest to proces dość skomplikowany, zdaniem Kazimierza Dąbrowskiego wymaga on wielopłaszczyznowej dezintegracji pozytywnej, dzięki której przechodzimy z życia instynktownego, stadnego na poziom życia indywidualnego, gdzie podstawą sądów moralnych staje się własne ja powinnościowe, żyjące w świecie wyższych wartości, w tym wartości moralnych ${ }^{25}$.

W nurcie poznawczo-rozwojowym psychologii podkreśla się mocniej niż w innych nurtach aktywny udział podmiotu we wszystkich fazach kształtowania jego tożsamości moralnej, sumienia. Akcentuje się jego poznawczą rolę w formowaniu sądów moralnych, w przeżywaniu emocjonalnej aprobaty lub dezaprobaty. Podkreśla się nawet rolę cnót w integracji, umocnieniu naszej tożsamości moralnej, niejako siły naszego ego wobec trudności i konfliktów ${ }^{26}$.

Da się zauważyć pewne podobieństwa między psychologicznym i fenomenologicznym ujęciem sumienia. Można powiedzieć, że w fazie konformizmu kierujemy się pseudonormami społecznymi, legalizmem względem norm państwowych, społecznych, kulturowych. Ulegamy su-

23 Por. P. Kurtek, A. Lasota, Wybrane psychologiczne aspekty struktury i rozwoju sumienia, w: Fenomen sumienia, dz. cyt., s. 59.

${ }^{24}$ P. Kurtek, A. Lasota, Wybrane psychologiczne aspekty struktury i rozwoju sumienia, dz. cyt., s. 62 .

${ }^{25}$ Por. K. Dąbrowski, Osobowość i jej ksztattowanie poprzez dezintegrację pozytywną, Lublin 1984, passim.

${ }^{26}$ Por. P. Kurtek, A. Lasota, Wybrane psychologiczne aspekty struktury i rozwoju sumienia, dz. cyt., s. 64 . 
biektywnym przyjemnościom generowanym przez instynktowne ja pożądliwe i pyszne. Zmierzając do dojrzałości moralnej, podmiotowej, osobowej, autonomicznej, staramy się, aby nasze ja prawe-pokorne-miłujące przezwyciężyło negatywne centra osobowe i stało się podstawą sądów moralnych.

Wysiłek, by oddać głos temu ja, by zrzucić z siebie pseudonormy na rzecz autentycznej moralności, wiąże Hildebrand z nabywaniem odpowiednich postaw moralnych. Opis tych postaw zawarty jest zarówno w wydanej w Niemczech w 1933 roku, w obliczu powstającej ideologii nazistowskiej, książce zatytułowanej: Fundamentalne postawy moralne (Sittliche Grundhaltunegen), jak też w poszerzonej wersji tej publikacji, wydanej w USA w 1965 roku: Sztuka życia (The Art of Living) ${ }^{27}$. Oprócz fundamentalnych postaw wymienionych w pierwszej pozycji, takich jak prawość, wierność, poczucie odpowiedzialności, dobroć i poszanowanie prawdy, w drugiej dodana została m.in. postawa nadziei oraz rola cnót. W psychologiczne czy osobowościowe dojrzewanie moralne wpisuje Hildebrand dojrzewanie duchowe, związane z osobową więzią z Jezusem Chrystusem, z nawróceniem, wewnętrzną przemianą. Zjawiska te opisuje w dziele Przemienieni w Chrystusie, gdzie oprócz takich postaw, jak skrucha, prostota, pokora, mamy opisane postawy związane z więzią duchową z Bogiem, takie jak zaufanie Bogu, święta cierpliwość, święta łagodność, święte miłosierdzie, święty żal, oddanie swojego ja.

Dzieła propagujące dojrzałą moralność Hildebrand publikował w dramatycznym czasie powstawania w Niemczech niebezpiecznej ideologii nazistowskiej, która opanowywała szerokie rzesze tego narodu. Już u źródeł owej groźnej ideologii demaskował on pseudonormy, którymi się posługiwała i przeciwstawiał jej moralność chrześcijańską. Dziś jego opisy autentycznej moralności personalistycznej i chrześcijańskiej można zastosować do zdemaskowania obecnie powstających ideologii, które narzucają swój zestaw pseudonorm zamiast autentycznych norm moralnych. Można je wykorzystać do zdemaskowania ideologii sekula-

27 D. v. Hildebrand, Fundamentalne postawy moralne, tł. K. Meissner OSB, w: Wobec wartości, Kraków 1984, s. 11-54; D. v. Hildebrand, A. v. Hildebrand, The Art of Living, Chicago 1965. 
rystycznych, niszczących związek moralności z tym, co transcendentne, wieczne, Boskie. Można je również użyć do zdemaskowania pseudomoralnych zasad neomarksistowskiej ideologii gender, która narzuca społeczeństwu w praktyce nowe niszczące utopie, poprzez różne formy inżynierii społecznej, nie tyle realizowanej - jak w marksizmie - oddolnie, ile narzucanej odgórnie poprzez różne, międzynarodowe, wpływowe, silne instytucje i organizacje społeczne.

\section{Bibliografia}

Biesaga T., Dietricha von Hildebranda epistemologiczno-ontologiczne podstawy etyki, Lublin 1989.

Biesaga T., Emocjonalna odpowiedź na wartość u podstaw życia moralnego, w: Konteksty podmiotowej świadomości, red. E. Podrez, R. Moń, Olecko 2003 (Episteme, 29), s. 91-100.

Biesaga T., Spór o normę moralności, Kraków 1998.

Biesaga T., Świadomościowe i osobowe warunki odpowiedzialności, w: O odpowiedzialności. Moralny wymiar odpowiedzialności w życiu publicznym, red. J. Pawlica, Kraków 1993, s. 67-74; oraz w: „Studia Philosophiae Christianae” 29 (1993) nr 2, s. 27-37.

Dąbrowski K., Osobowość i jej ksztattowanie poprzez dezintegrację pozytywną, Lublin 1984.

Fenomen sumienia, red. D. Adamczyk, Kielce 2012.

Gorczyca J., Dietricha von Hildebranda koncepcja poznania wartości moralnych, „Analecta Cracoviensia" 19 (1987), s. 427-439.

Hildebrand D. von, Christian Ethics, New York 1952; wyd. niem. Ethik, Regensburg 1973 (Gesammelte Werke, 2).

Hildebrand D. von, Fundamentalne postawy moralne, tł. K. Meissner OSB, w: Wobec wartości, Kraków 1984, s. 11-54.

Hildebrand D. von, Graven Images: Substitutes for True Morality, New York 1957; wyd. niem. Substitute für wahre Sittlichkeit, w: Idolkult und Gotteskult, Regensburg 1974, s. 13-190 (Gesammelte Werke, 7).

Hildebrand D. von, Liturgie und Pesönlichkeit, w: Idolkult und Gotteskult, Regensburg 1974, s. 191-300 (Gesammelte Werke, 7).

Hildebrand D. von, Przemienienie w Chrystusie, tł. J. Zychowicz, Kraków 1982. 
Hildebrand D. von, Hildebrand A. von, The Art of Living, Chicago 1965.

Kurtek P., Lasota A., Wybrane psychologiczne aspekty struktury i rozwoju sumienia, w: Fenomen sumienia, red. D. Adamczyk, Kielce 2012, s. 53-70.

Murawski K., Jaźń i sumienie. Filozoficzne zagadnienia rozwoju duchowego człowieka w pracach Carla Gustawa Junga i Antoniego Kępińskiego, Wrocław 1987.

Stach R., Sumienie i mózg. O wewnętrznym regulatorze zachowań moralnych, Kraków 2012. Wiśniewska D., Rodzaje i rola substytutów w moralności w ujęciu Dietricha von Hildebranda, „Logos i Ethos” 2014 nr 2 (37), s. 77-98.

\section{Abstrakt \\ Deformacje sumienia. Pseudonormy w ujęciu Dietricha von Hildebranda}

Artykuł przedstawia opis pseudonorm moralnych, które w naszej świadomości i w działaniu wypierają właściwe normy moralne oraz wypaczają naszą moralność. Analizuje głównie pseudonormy, które rodzą postawy legalizmu, i przeciwne im postawy anarchizmu moralnego. Pierwsze utożsamiają moralność z prawem stanowionym, w tym szczególnie z prawem karnym, drugie przeciwnie - utożsamiają moralność z tym, co spontaniczne, impulsywne, autentyczne.

Artykuł nie tylko analizuje zakresowe i treściowe zniekształcenia przez substytuty moralności norm moralnych, ale i ujawnia powody powstawania pseudonorm w naszej świadomości. Powodami tymi są wpływ na naszą odpowiedź na wartości ja pysznego i ja pożądliwego oraz przedkładanie wartości pozamoralnych nad wartości moralne.

Zdemaskowanie funkcjonowania pseudonorm w naszej świadomości moralnej jest przydatne nie tylko dla etyki, ale i dla psychologii i pedagogiki, dla samowychowania i rozwoju moralnego.

\section{Słowa kluczowe}

Dietrich von Hildebrand, pseudonormy, legalizm, anarchizm, antymoralne teorie, antymoralne ideologie, wartości moralne, wartości pozamoralne, odpowiedź na wartość, ja prawe-pokorne-miłujące, ja pyszne, ja pożądliwe 


\section{Abstract \\ Deformation of Conscience. Pseudo-Norms in Terms of Dietrich von Hildebrand}

The paper presents a description of moral pseudo-norms, which displace proper moral norms from our consciousness and action as well as distort our morality. The study analyzes mainly the pseudo-norms that generate the fundamentals of legalism and their opposition - the fundamentals of moral anarchism. The first groups of pseudo-norms identifies morality with civil law, especially criminal law. On the other hand the other group of pseudo-norms, equates morality with what is spontaneous, impulsive, authentic.

The paper analyzes not only the scope- and content-related distortion of moral norms caused by the substitutes of morality, but it also reveals the reasons of creating the pseudonorms in our consciousness. These reasons are induced by the impact of the pride center and the concupiscent center on our value response and by preferring the extra-moral values over the moral ones.

Exposing the mechanism of functioning of the pseudo-norms in our moral consciousness is useful not only for ethics but also for psychology and pedagogy as well as for self-education and moral development.

\section{Keywords}

Dietrich von Hildebrand; pseudo-norms; legalism; anarchism; extra-moral theories; extra-moral ideologies; moral values; extra-moral values; value response; reverenthumble-loving center; concupiscent center; pride center 